\title{
Joanna Wiszniewska*
}

\section{Zakaz reklamy aptek i ich działalności - geneza wprowadzenia i ocena regulacji}

\section{Spis treści}

I. Wprowadzenie zakazu reklamy aptek w odniesieniu do asortymentu refundowanego

1. Przyczyny wprowadzenia art. 94a prawa farmaceutycznego

2. Orzecznictwo sądowoadministracyjne w oparciu o art. 94a prawa farmaceutycznego - wzmianka

3. Ocena częściowego zakazu reklamy aptek

II. Całkowity zakaz reklamy aptek i ich działalności

1. Pierwsze próby wprowadzenia regulacji

2. Wprowadzenie całkowitego zakazu przy okazji uchwalenia ustawy refundacyjnej

3. Ocena sposobu wprowadzenia całkowitego zakazu reklamy aptek

4. Stanowisko Ministerstwa Zdrowia

5. Ocena merytoryczna zakazu

6. Perspektywy nowelizacji zakazu reklamy aptek

7. Skargi konstytucyjne

III. Podsumowanie

\section{Streszczenie}

Przedmiotem artykułu jest omówienie genezy wprowadzenia zakazu reklamy aptek do polskiego systemu prawnego. W części pierwszej skupiono się na przyczynach wprowadzenia w 2007 r. częściowego zakazu reklamy aptek w odniesieniu do asortymentu refundowanego przez Narodowy Fundusz Zdrowia i ocenie tej regulacji. Część druga pracy poświęcona została całkowitemu zakazowi reklamy aptek i ich działalności, który funkcjonuje w Polsce od początku 2012 r. Podjęto w niej próbę merytorycznej oceny zarówno samego zakazu, jak i sposobu jego wprowadzenia. Omówiono także aktualne inicjatywy w zakresie zniesienia lub zmiany brzmienia regulacji.

Słowa kluczowe: reklama aptek; reklama produktów leczniczych.

JEL: K23.

\footnotetext{
Radca prawny; magister farmacji; doktorantka w Katedrze Prawa Własności Intelektualnej Wydziału Prawa i Administracji Uniwersytetu Jagiellońskiego; e-mail: joanna.wiszniewska@doctoral.uj.edu.pl.
} 


\section{Wprowadzenie zakazu reklamy aptek w odniesieniu do asortymentu refundowanego}

Obowiązujący w polskim systemie prawnym od 1 stycznia 2012 r. całkowity zakaz reklamy aptek i ich działalności jest rozwiązaniem tyleż kontrowersyjnym, co unikatowym w skali światowej. W kontekście toczącej się aktualnie dyskusji nad możliwością i celowością jego zmiany oraz skargami konstytucyjnymi skierowanymi do Trybunału Konstytucyjnego warto prześledzić genezę wprowadzenia tej regulacji oraz podejmowane już próby jej zmiany.

W pierwotnym brzmieniu prawa farmaceutycznego ${ }^{1}$, które - co do zasady - zaczęło obowiązywać 1 października 2002 r., ustawodawca w ogóle nie zawarł regulacji dotyczących reklamy aptek. Stan ten uległ zmianie z dniem 1 maja 2007 r., od kiedy zaczął obowiązywać art. 94a prawa farmaceutycznego ${ }^{2}$ w następującym brzmieniu:

Art. 94a. 1. Zabroniona jest reklama działalności aptek lub punktów aptecznych skierowana do publicznej wiadomości, która w sposób bezpośredni odnosi się do produktów leczniczych lub wyrobów medycznych umieszczonych na wykazach leków refundowanych, lub produktów leczniczych lub wyrobów medycznych o nazwie identycznej z nazwą produktów leczniczych lub wyrobów medycznych umieszczonych na tych wykazach.

2. Wojewódzki inspektor farmaceutyczny sprawuje nadzór nad przestrzeganiem przepisów ustawy w zakresie działalności reklamowej aptek i punktów aptecznych.

3. W razie stwierdzenia naruszenia przepisu ust. 1 wojewódzki inspektor farmaceutyczny nakazuje, w drodze decyzji, zaprzestanie prowadzenia takiej reklamy.

4. Decyzji, o której mowa w ust. 3, nadaje się rygor natychmiastowej wykonalności.

\section{Przyczyny wprowadzenia art. 94a prawa farmaceutycznego}

Przed wprowadzeniem częściowego zakazu reklamy aptek obowiązywała w tym zakresie dowolność, ograniczona jedynie przez reguły ogólne związane z reklamą ${ }^{3}$. Wprowadzenie szczegółowej regulacji dotyczącej reklamy aptek miało na celu wyeliminowanie niektórych działań marketingowych wykorzystywanych przez przedsiębiorców prowadzących apteki.

Polegały one przede wszystkim na promocjach cenowych leków - w tym także tych znajdujących się na listach refundacyjnych - w ten sposób, iż odpłatność pacjenta wynosiła np. 1 zł lub wręcz $1 \mathrm{gr}$ (por. Koremba, 2009). Różnicę pomiędzy odpłatnością wskazaną na liście refundacyjnej a faktyczną kwotą zapłaconą przez pacjenta, pokrywał organizator promocji, najczęściej właściciel apteki. Niezależnie od sumy, jaką zapłacił pacjent, apteka otrzymywała refundację z Narodowego Funduszu Zdrowia. Pacjenci, zachęceni promocyjnymi cenami, realizowali w oferujących je aptekach także recepty na leki nierefundowane. Dokonywali tam również innych zakupów, np. kosmetyków i suplementów diety, co - w ostatecznym rozrachunku - przynosiło przedsiębiorcy prowadzącemu aptekę zysk znacznie przewyższający kwotę udzielonego rabatu. W innych przypadkach za realizację recept pacjentom oferowano prezenty lub bony wartościowe. Działania takie przede wszystkim, choć nie wyłącznie, prowadziły apteki sieciowe. Ponieważ tego

\footnotetext{
Ustawa z 6.09.2001 r. - Prawo farmaceutyczne (Dz.U. 2001 Nr 126, poz. 1381). Późniejsze odwołania - jeśli nie oznaczono inaczej - odnoszą się do tekstu jednolitego Dz.U z 2008 r. Nr 45, poz. 271, ze zm.; dalej: prawo farmaceutyczne.

2 Dodany przez art. 1 pkt 79 ustawy z 30.03.2007 r. o zmianie ustawy - Prawo farmaceutyczne oraz zmianie niektórych innych ustaw (Dz.U. 2007 $\mathrm{Nr}$ 75, poz. 492)

3 Chodzi zwłaszcza o art. 16 ustawy z 16.04.1993 r. o zwalczaniu nieuczciwej konkurencji, (t.j. Dz.U. 2003 Nr 153, poz.1503, ze zm.).
} 
typu promocje służyły często obejściu zakazu reklamy produktów objętych listą refundacyjną oraz mogły skutkować zwiększeniem nakładów przeznaczanych przez Narodowy Fundusz Zdrowia na refundację produktów leczniczych i wyrobów medycznych ustawodawca zdecydował się wprowadzić w tym zakresie regulacje (Por. Harasymiuk, 2011, pkt 3.2.4).

Jakkolwiek w przywołanym powyżej brzmieniu art. 94a prawa farmaceutycznego ustawodawca nie sprecyzował, jakie działania uznawane są za reklamę, to ze sposobu sformułowania przepisu wyraźnie widać, iż największy nacisk położony został na produkty lecznicze i wyroby medyczne objęte refundacją. Rozwiązania wątpliwości interpretacyjnych pojęcia reklamy próżno szukać w uzasadnieniu projektu zmian, ponieważ w odniesieniu do nich autorzy rządowego projektu poinformowali jedynie, iż „(...) wprowadzono kilka zmian mających na celu rozwiązanie wątpliwości interpretacyjnych związanych z obecnie istniejącą regulacją prawną z zakresu reklamy produktów leczniczych oraz kwestii dopuszczalności prowadzenia działań promocyjnych przez apteki ogólnodostępne lub punkty apteczne"4.

Warto zauważyć, iż żaden z podmiotów biorących udział w konsultacjach społecznych projektu ustawy ${ }^{5}$ nie zwrócił uwagi na brzmienie art. 94a prawa farmaceutycznego i jego możliwe konsekwencje. Tymczasem, tą samą ustawą wprowadzono jednocześnie szereg innych regulacji, w tym związanych z reklamą produktów leczniczych ${ }^{6}$ i wzbudziły one liczne kontrowersje $\mathrm{m}$.in. ze względu na brak wystarczającej precyzji użytych pojęć.

Wprowadzenie częściowego zakazu reklamy aptek, jednocześnie z implementacją przepisów wspólnotowych dotyczących podobnej materii, miało jeszcze jeden, dość nieoczekiwany skutek. Wojewódzki Sąd Administracyjny w Warszawie w uzasadnieniach niektórych orzeczeń wskazał, że skoro art. 94a prawa farmaceutycznego został wprowadzony do polskiego porządku prawnego ustawą, która implementowała m.in. wspomniane wyżej dyrektywy, to Polska, jako państwo członkowskie Unii Europejskiej, zobowiązana jest do jej wykonania poprzez odpowiednie przepisy prawa krajowego ${ }^{7}$. Choć jest to stwierdzenie prawdziwe, w żadnej mierze nie uzasadnia konieczności wprowadzenia ani egzekwowania zakazu reklamy aptek, ponieważ przepisy unijne takich regulacji nie przewidują.

Na skutki wprowadzenia omawianej regulacji nie trzeba było długo czekać. Wojewódzkie inspektoraty farmaceutyczne zaczęły masowo wydawać decyzje w przedmiocie zakazania prowadzonej przez apteki reklamy ${ }^{8}$.

\section{Orzecznictwo sądowoadministracyjne w oparciu o art. 94a prawa farmaceutycznego - wzmianka}

Analiza orzecznictwa dotyczącego reklamy aptek nie jest przedmiotem niniejszej pracy, jednak dla porządku rozważań warto przytoczyć kilka wyroków sądów administracyjnych. W toku postępowania odwoławczego w samym tylko 2007 r. do Wojewódzkiego Sądu Administracyjnego

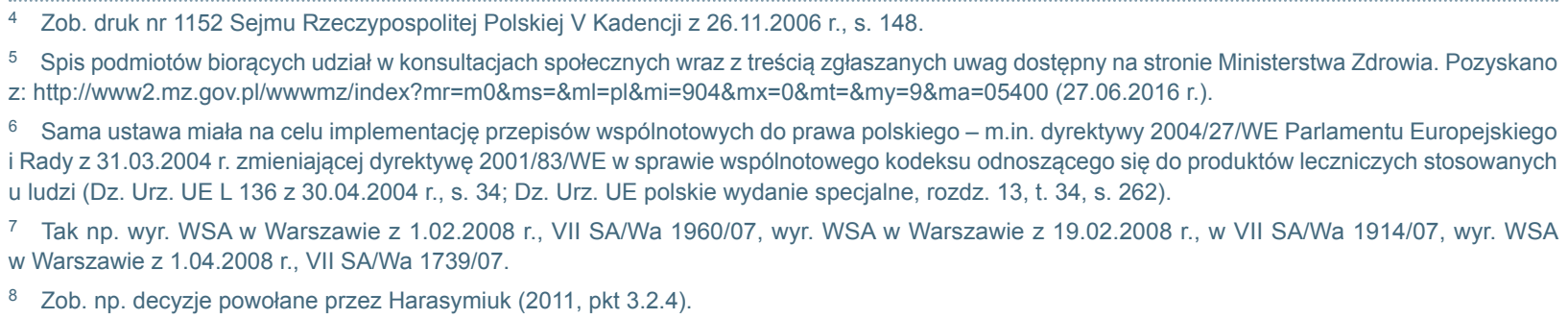


w Warszawie wpłynęło kilkanaście skarg związanych z interpretacją zakazu zawartego w art. 94a prawa farmaceutycznego. We wszystkich sprawach skargi zostały oddalone z niemal identycznymi uzasadnieniami. Składy orzekające każdorazowo podkreślały brak definicji reklamy apteki (w przeciwieństwie do zdefiniowanej w art. 52 prawa farmaceutycznego reklamy produktu leczniczego) i konieczność odwołania się do wykładni językowej tego pojęcia, przy czym niemal we wszystkich sprawach powoływano się na definicję zawartą w Wielkim Słowniku Wyrazów Obcych pod red. M. Bańki (2003).

Sądy w poszczególnych sprawach stosowały maksymalnie rozszerzającą wykładnię pojęcia reklamy. W sprawie dotyczącej list cenowych publikowanych przez jedną z sieci aptecznych, Wojewódzki Sąd Administracyjny w Warszawie orzekł, iż „reklamą apteki jest każda działalność przez nią powadzona, niezależnie od jej formy i metody przeprowadzenia, która ma na celu zwiększenie sprzedaży w niej wyrobów medycznych lub produktów leczniczych"9.

$\mathrm{Na}$ tym tle, na uwagę zasługuje orzeczenie, które zapadło przed Wojewódzkim Sądem Administracyjnym w Warszawie w sprawie o sygnaturze VII SA/Wa 698/08 ${ }^{10}$. Sprawa dotyczyła skargi wniesionej na decyzję wydaną przez Wojewódzkiego Inspektora Farmaceutycznego, a podtrzymaną przez Głównego Inspektora Farmaceutycznego nakazującą m.in. „zaprzestanie prowadzenia w aptece działalności marketingowej, niezgodnej z art. 86 ust. 1 i 2 Prawa farmaceutycznego, polegającej na wręczaniu bonów o wartości 10 zł”. W niniejszej sprawie sąd również przyjął bardzo szeroką wykładnię pojęcia reklamy apteki. Co więcej - w opinii Autorki niezasadnie - uznał, iż organy administracyjne błędnie zakwalifikowały rozdawanie bonów jako działania marketingowe, gdyż „działalność ta nie jest niczym innym, jak reklamą działalności apteki, o której mowa w art. 94a Prawa farmaceutycznego".

Istotną nowością jest jednak podkreślenie przez sąd, że „ustawodawca dopuścił, co do zasady, możliwość prowadzenia działalności reklamowej apteki, wyłączając jedynie reklamę działalności aptek lub punktów aptecznych skierowaną do publicznej wiadomości, która w sposób bezpośredni odnosi się do produktów leczniczych lub wyrobów medycznych umieszczonych na wykazach leków refundowanych". W konsekwencji sąd przyjął, iż nie doszło do naruszenia zakazu, o którym mowa w art. 94a prawa farmaceutycznego, ponieważ bony nie były bezpośrednio powiązane $z$ wymienionym tam asortymentem.

Podsumowania linii orzeczniczej dotyczącej art. 94a prawa farmaceutycznego można upatrywać w orzeczeniu Wojewódzkiego Sądu Administracyjnego z dnia 20 września 2010 r. ${ }^{11}$. Sprawa dotyczyła ustalenia czy ulotki reklamowe wydawane przez sieć aptek stanowią reklamę ich działalności (w rozumieniu art. 94a prawa farmaceutycznego), czy też reklamę produktów leczniczych w niej wymienionych (w rozumieniu art. 52 ust. 1 prawa farmaceutycznego). Rozstrzygnięcie decydowało o właściwości organu administracyjnego sprawującego nadzór nad reklamą (odpowiednio Wojewódzki Inspektor Farmaceutyczny lub Główny Inspektor Farmaceutyczny, który uznał się w przedmiotowej sprawie za niewłaściwy). Skarżącym był Rzecznik Odpowiedzialności Zawodowej w jednej z okręgowych izb aptekarskich, w opinii którego, foldery reklamowe należy

\footnotetext{
9 Wyr. WSA w Warszawie z 19.02.2008 r., VII SA/Wa 1914/07. Bardzo podobne stanowisko zajęły składy orzekające w wyr. WSA w Warszawie z 6.03.2008 r., VII SA/Wa 2216/07 oraz wyr. WSA w Warszawie z 22.11.2007 r., VII SA/Wa 1661/07.

10 Wyr. WSA w Warszawie z 17.10.2008 r., VII SA/Wa 698/08, LEX nr 527533. Sprawa ta rozpoznawana była również przez NSA, który oddalił skargę kasacyjną złożoną przez Głównego Inspektora Farmaceutycznego (wyr. NSA z 7.10.2009 r., II GSK 100/09).

11 Wyr. WSA w Warszawie z 17.10 .2008 r., VII SA/Wa 838/10.
}

internetowy Kwartalnik Antymonopolowy i Regulacyjny 2016, nr 8(5) • www.ikar.wz.uw.edu.pl • DOI: 10.7172/2299-5749.IKAR.8.5.2 
uznać za wizualną reklamę produktów leczniczych, ponieważ „zachęcają do stosowania przedstawionych produktów leczniczych oraz zwiększenia liczby ich sprzedaży i konsumpcji” ${ }^{12}$.

Wojewódzki Sąd Administracyjny podzielił stanowisko skarżonego organu, tj. Głównego Inspektora Farmaceutycznego. W uzasadnieniu wyroku Sąd podkreślił, iż „[z]a reklamę apteki należy uznać wszelkie działania polegające na informowaniu i zachęcaniu do zakupu produktu leczniczego lub wyrobu medycznego w danej aptece lub punkcie aptecznym mającą na celu zwiększenie ich sprzedaży. Taki właśnie charakter posiadają foldery sieci aptek (...), które zachęcają klientów do nabywania leków po obniżonych cenach w tych właśnie aptekach, których adresy zostały wyszczególnione w ulotce. $\mathrm{W}$ istocie gazetki reklamują przede wszystkim apteki poprzez podanie korzyści, jakie płyną z zaopatrywania się w tych właśnie aptekach"13.

\section{Ocena częściowego zakazu reklamy aptek}

Po pierwsze, istotnym argumentem podnoszonym zarówno w toku prac legislacyjnych, jak i już po wprowadzeniu zakazu była korzyść ekonomiczna Skarbu Państwa. Rzeczywiście, sprzedawanie refundowanych produktów leczniczych lub wyrobów medycznych w symbolicznie niskich cenach, mogło prowadzić do zwiększenia wydatków Narodowego Funduszu Zdrowia spowodowanych kupowaniem przez pacjentów leków „na zapas”. Należy jednak pamiętać, iż cały refundowany asortyment apteki wydają jedynie na podstawie ważnej recepty lekarskiej. Dlatego też, nawet najkorzystniejsze dla pacjenta ceny czy też chęć skorzystania z wyjątkowo atrakcyjnej promocji, nie będą miały wpływu na zakupienie większej ilości leków niż przepisana przez lekarza.

Po drugie, spośród wszystkich działań marketingowych ${ }^{14}$ ustawodawca zdecydował się na wprowadzenie zakazu reklamy. W opinii Autorki, było to rozwiązanie najzupełniej błędne i świadczące o niezrozumieniu mechanizmów działań marketingowych. W istocie, dla osiągnięcia pożądanego przez ustawodawcę celu należałoby wprowadzić zakaz promocji sprzedaży, ewentualnie, by wyeliminować wszelkie wątpliwości, zakaz łączenia promocji z reklamą. Nie sama reklama (np. w postaci ulotki) była wszakże magnesem, który przyciągał pacjentów do tej, a nie innej apteki, ale niższe niż w konkurencyjnej placówce ceny.

Podsumowując, w stanie prawnym obowiązującym po 1 maja 2007 r., mimo tendencji do rozszerzającej (obejmującej bowiem także inne formy działalności marketingowej) interpretacji pojęcia reklamy, apteki mogły prowadzić wszelkiego typu działania marketingowe, w tym także reklamowe - pod warunkiem, że nie dotyczyły one bezpośrednio ani nie były związane z produktami objętymi refundacją ${ }^{15}$. Co więcej niedozwolona była tylko reklama publiczna, toteż zakaz nie obejmował reklamy skierowanej do konkretnego indywidualnego pacjenta. W literaturze podnosi się - zdaniem Autorki trafnie - iż względny zakaz reklamy w brzmieniu wprowadzonym w 2007 r. stanowił „rozsądne jej ograniczenie” (zob. Ogiegło, 2015, art. 94a, Nb. 2). 


\section{Całkowity zakaz reklamy aptek i ich działalności}

\section{Pierwsze próby wprowadzenia regulacji}

Pierwszą próbę zaostrzenia regulacji dotyczącej reklamy aptek odnaleźć można w projekcie z dnia 3 listopada 2008 r. ustawy o zmianie ustawy - Prawo farmaceutyczne oraz o zmianie niektórych innych ustaw ${ }^{16}$. Projekt ten został w listopadzie 2008 r. przekazany do konsultacji społecznych rozmaitym podmiotom ${ }^{17}$, m.in. UOKiK oraz Naczelnej Izbie Aptekarskiej ${ }^{18}$, gdzie spotkał się ze skrajnie różnym przyjęciem.

Ustawodawca motywował zmiany koniecznością zwiększenia ochrony pacjentów i finansów publicznych przed ujemnymi skutkami reklamy aptek oraz objęciem farmaceutów zakazami podobnymi, jak w przypadku innych wolnych zawodów (np. lekarzy czy radców prawnych) ${ }^{19}$. Podkreślono również, że sposób działania apteki jest jednoznacznie regulowany przez prawo, zatem „reklama odnosząca się do zakresu i jakości usług farmaceutycznych nie ma żadnego uzasadnienia" 20.

W stanowisku Prezesa UOKiK złożonym w odpowiedzi na projekt nowelizacji ${ }^{21}$, planowane zmiany zostały ocenione jednoznacznie negatywnie, wręcz jako „nie do przyjęcia”. Małgorzata Krasnodębska-Tomkiel wskazała, iż proponowana zmiana może nie tylko ograniczyć swobodę działalności gospodarczej, lecz także negatywnie wpłynąć na najsłabszego uczestnika rynku farmaceutycznego, jakim jest pacjent (konsument). W opinii prezes UOKiK dopuszczalne są ograniczenia reklamy tak, by decyzje pacjenta nie były podejmowane pod wpływem błędnych przekonań, jednak sama reklama nie powinna być zakazana, gdyż jej głównym atrybutem jest korzyść zarówno po stronie konsumenta, jak i prowadzącego działalność gospodarczą. Dzięki reklamie pacjent może znaleźć aptekę jak najbardziej dostosowaną do swoich potrzeb. Wprowadzenie zakazu jest tym bardziej niecelowe, że dopuszczalna jest reklama samych leków dostępnych bez recepty (tzw. OTC).

Z kolei stanowisko Naczelnej Izby Aptekarskiej było zdecydowanie entuzjastyczne. Samorząd aptekarski zgłosił wprawdzie szereg uwag związanych z uzupełnieniem czy doprecyzowaniem propozycji ministerialnych, jednak uznał, iż „niektóre z [proponowanych] norm mogły (...) uchronić polskie apteki przed likwidacją i powstrzymać postępującą pauperyzację farmaceutów"22.

Ze względu na liczbę i wagę komentarzy zgłoszonych do projektu w ramach uzgodnień wewnętrznych i konsultacji społecznych Ministerstwo Zdrowia wycofało projekt w dniu 26 marca 2009 r. z Planu Pracy Rządu na I półrocze 2009 r. ${ }^{23}$ i ostatecznie nie był on już dalej procedowany.

Następnie, 28 kwietnia 2009 r., Minister Zdrowia powołał Zespół do spraw opracowania projektu ustawy - Prawo farmaceutyczne, co spotkało się ze zdecydowaną krytyką NIA ${ }^{24}$ i kontynu-

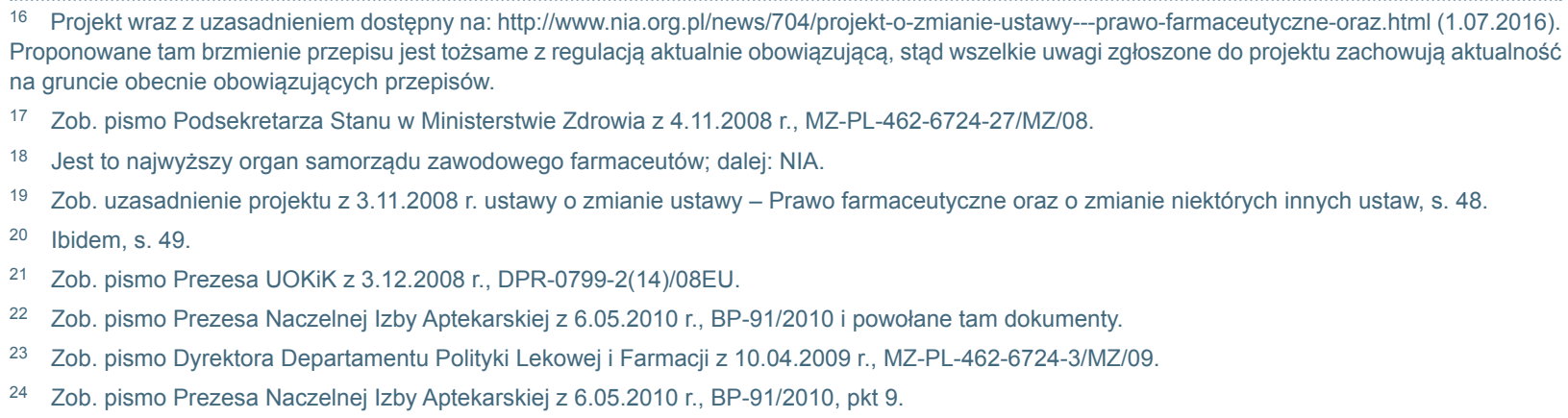


owaniem przez organ samorządu zawodowego intensywnej działalności lobbingowej na rzecz wprowadzenia całkowitego zakazu reklamy ${ }^{25}$.

\section{Wprowadzenie całkowitego zakazu przy okazji uchwalenia ustawy refundacyjnej}

W dniu 18 października 2010 r. Prezes Rady Ministrów przedstawił Marszałkowi Sejmu projekt ustawy o refundacji leków, środków spożywczych specjalnego przeznaczenia żywieniowego oraz wyrobów medycznych ${ }^{26}$. Projekt obejmował kompleksową regulację zasad refundacyjnych i zawierał nieliczne zmiany w przepisach obowiązujących, wynikające one przede wszystkim z konieczności ich dostosowania do wprowadzanych regulacji. W takim brzmieniu został skierowany do Komisji Zdrowia, a następnie w dniu 14 grudnia 2010 r. do prac Nadzwyczajnej Podkomisji Zdrowia do spraw rozpatrzenia projektu ustawy o refundacji leków, środków spożywczych specjalnego przeznaczenia żywieniowego oraz wyrobów medycznych. W trakcie prac Podkomisji, na wniosek przedstawiciela NIA, do projektu ustawy wprowadzono poprawkę zmieniającą brzmienie art. 94a prawa farmaceutycznego.

W konsekwencji z dniem 1 stycznia 2012 r. wszedł w życie przepis art. 94a prawa farmaceutycznego w znowelizowanym brzmieniu ${ }^{27}$. Oprócz zmiany treści ust. 1 omawianego przepisu ustawodawca wprowadził ust. 1a. Od 1 stycznia 2012 r. regulacje te przyjęły następujące brzmienie:

1. Zabroniona jest reklama aptek i punktów aptecznych oraz ich działalności. Nie stanowi reklamy informacja o lokalizacji i godzinach pracy apteki lub punktu aptecznego.

1a. Zabroniona jest reklama placówek obrotu pozaaptecznego i ich działalności odnosząca się do produktów leczniczych lub wyrobów medycznych.

\section{Ocena sposobu wprowadzenia całkowitego zakazu reklamy aptek}

Jak słusznie podnoszą praktycy prawa, wprowadzenie poprawki odbyło się z naruszeniem wszystkich zasad prawidłowej legislacji28 i nie sposób takich działań zaaprobować.

Po pierwsze, projekt z dnia 18 października 2010 r. ustawy o refundacji leków, środków spożywczych specjalnego przeznaczenia żywieniowego oraz wyrobów medycznych ${ }^{29}$ nie zawierał zakazu reklamy aptek, więc siłą rzeczy nie można znaleźć w nim żadnego uzasadnienia, którym kierowałby się rząd. W tym stanie można odwołać się jedynie do wspominanego już powyżej uzasadnienia projektu z dnia 3 listopada 2008 r. ustawy o zmianie ustawy - Prawo farmaceutyczne oraz o zmianie niektórych innych ustaw.

Po drugie, regulację ograniczającą w istotny sposób prawa i wolności przedsiębiorców prowadzących apteki wprowadzono w brzmieniu postulowanym przez jedną tylko z zainteresowanych stron, tj. przedstawicieli samorządu aptekarskiego. Nie przeprowadzono żadnych uzgodnień międzyresortowych, konsultacji społecznych, analizy skutków regulacji czy opiniowania pod kątem zgodności z Konstytucją. Jest to tym bardziej zaskakujące, że regulacja identycznej treści,

\footnotetext{
25 Zob. np. pismo Prezesa Naczelnej Izby Aptekarskiej z 5.08.2009 r., BP-251/2009 - uwagi do projektu ustawy o zmianie ustawy - Prawo farmaceutyczne w wersji z 17.07.2009 r. z postulatem wprowadzenia całkowitego zakazu reklamy aptek czy pismo Prezesa Naczelnej Izby Aptekarskiej do Minister Zdrowia z 5.08.2009 r., BP-250/2009.

26 Druk nr 3491 z 18.10.2010 r., RM 10-140-10, sejm VI kadencji.

27 Wprowadzony w art. 60 pkt 7 ustawy z 12.05.2011 r. o refundacji leków, środków spożywczych specjalnego przeznaczenia żywieniowego oraz wyrobów medycznych (Dz.U. $2011 \mathrm{Nr} 122$, poz. 696).

28 Zob. Skarga konstytucyjna z 16.03.2015 r., SK 23/15 oraz Skarga konstytucyjna z 3.06. 2015 r., SK 32/15.

29 Druk nr 3491 z 18.10.2010 r., RM 10-140-10, sejm VI kadencji.
}

internetowy Kwartalnik Antymonopolowy i Regulacyjny 2016, nr 8(5) • www.ikar.wz.uw.edu.pl • DOI: 10.7172/2299-5749.IKAR.8.5.2 
proponowana w projekcie ustawy z 2008 r., została przecież bardzo krytycznie oceniona przez prezesa UOKiK ${ }^{30}$.

Po trzecie, wprowadzony w brzmieniu nadanym przez NIA zakaz narusza zasadę określoności przepisów prawa. Sytuację taką należy ocenić tym bardziej negatywnie, że problemy ze sposobem sformułowania przepisu i rozumieniem pojęcia reklamy pojawiały się już w poprzednim jego brzmieniu, stąd - zakładając racjonalność ustawodawcy - należało spodziewać się ich tym bardziej przy zwiększeniu restrykcyjności zakazu. Tymczasem, mimo braku - nawet w języku nie-prawniczym - jednolitego rozumienia pojęcia reklamy ustawodawca nie zdecydował się na jego zdefiniowanie ${ }^{31}$. Jest to wyraźne pogwałcenie zasady określoności prawa, w sytuacji, w której przepis ogranicza prawa i wolności, wyznaczając jednocześnie zakres działań zagrożonych sankcją administracyjno-prawną.

Brak dookreślenia pojęcia reklamy jest istotny także w kontekście wspomnianego już nastawienia NIA, która aktywnie uczestniczy w procesie egzekwowania zakazu poprzez inicjowanie postępowań przed wojewódzkimi inspektorami farmaceutycznymi, przystępowanie do takich postępowań czy składanie zażaleń, w nielicznych przypadkach umorzenia postępowania ${ }^{32}$. Obfita korespondencja NIA z przedstawicielami różnych władz jednoznacznie pokazuje, iż zdaniem organu samorządu, do działań reklamowych zalicza także inne działania marketingowe i zwalcza np. stosowanie obniżek cen przez apteki ${ }^{33}$.

Wspomniane powyżej stanowisko NIA ${ }^{34}$ było również przedmiotem skargi do Rzecznika Praw Obywatelskich ${ }^{35}$ - w toku jej badania prezes NIA przedstawił pismo, w którym jeszcze raz wyraził swoje kategoryczne poglądy ${ }^{36}$. Osoby krytykujące zakaz i formę jego wprowadzenia określeni zostali jako „potężni przedsiębiorcy, najwięksi gracze na rynku usług farmaceutycznych, niezainteresowani pacjentem i jego potrzebami, [którzy] postanowili zwalczać, dezawuować i ośmieszać działania organów samorządu aptekarskiego". Prezes NIA zapewnił Rzecznika Praw Obywatelskich, iż „żaden farmaceuta, ani tym bardziej pacjent, nie może ucierpieć w sytuacji, gdy zakaz reklamy aptek będzie obowiązywać i będzie egzekwowany przez powołane do tego organy Państwa”. Zakaz reklamy aptek ma m.in. gwarantować pacjentom, że „W aptece spotka się z pracownikiem medycznym działającym na jego rzecz, a otoczenie będzie przyjazne i neutralne (bez reklam)". Niestety także i tym razem prezes NIA nie wyjaśnił, w jaki sposób otoczenie bez reklam apteki, ale za to wypełnione - zgodnymi z prawem - reklamami produktów leczniczych, będzie bardziej przyjazne i neutralne dla pacjenta.

\footnotetext{
Pismo Prezesa UOKiK z 3.12.2008 r., DPR-0799-2(14)/08EU

1 Co więcej Ministerstwo Zdrowia nie widziało takiej potrzeby, uznając - w opinii Autorki dość życzeniowo - że sprawa została rozwiązana przez dotychczasową (rzeczywiście spójną, choć nie zawsze zasługującą na aprobatę) praktykę organów Państwowej Inspekcji Farmaceutycznej oraz najnowsze orzecznictwo, które wypracowało definicję reklamy apteki - zob. np. odpowiedź z 15.05.2014 r. na interpelację poselską nr 25899.

32 Zob. np. pismo Prezesa Naczelnej Izby Aptekarskiej z 5.09.2012 r., P-201/2012.

33 Warto w tym miejscu wspomnieć, iż w opinii Ministerstwa Zdrowia „dozwolone jest sprzedawanie produktów po obniżonej cenie wraz z obowiązkowym wywieszeniem informacji o obniżce, tak by pacjent był poinformowany o cenie aktualnej” - por. np. odpowiedź z 31.10.2013 r. Podsekretarza Stanu w Ministerstwie Zdrowia - z upoważnienia ministra - na interpelację poselską 21536.

34 Stanowisko Nr VI/1/2012 z 11.04.2012 r. Naczelnej Rady Aptekarskiej w sprawie zakazu reklamy aptek i punktów aptecznych oraz ich działalności.

35 Zob. pismo Dyrektora Zespołu Administracyjnego i Gospodarczego w Biurze Rzecznika Praw Obywatelskich z 19.07.2012 r., PRO-703128-V/12/BA.

36 Zob. pismo Prezesa Naczelnej Izby Aptekarskiej z 1.09.2012 r., 206/2012.
} 


\section{Stanowisko Ministerstwa Zdrowia}

Warto jednocześnie zauważyć, iż resort zdrowia, choć w zasadzie popiera całkowity zakaz reklamy aptek ${ }^{37}$, odcina się od sposobu sformułowania przepisu, a w konsekwencji od powstałych na jego gruncie wątpliwości interpretacyjnych. Przedstawiciel Ministerstwa wielokrotnie podkreślał, iż „problematyczny zapis był inicjatywą, która wyszła od środowiska aptekarskiego, a konkretnie od samorządu aptekarskiego (...). Brzmienie rzeczonego przepisu zostało mu nadane na etapie prac parlamentarnych w sejmowej podkomisji zdrowia (...). Zmiana nastąpiła w końcowej fazie procesu legislacyjnego, kiedy to resort zdrowia nie partycypował już w procesie nadawania treści tworzonym lub zmienianym przepisom"38.

Z kolei jako ratio legis zakazu, Ministerstwo wskazuje „ograniczenie nadmiernej konsumpcji produktów leczniczych przez pacjentów, którzy zachęceni możliwością nabycia leku po promocyjnej cenie, czy też za tzw. 1 grosz, dokonywali licznych zakupów"39. W odpowiedzi na inną interpelację podaje z kolei, iż zakaz reklamy miał prowadzić do „ukrócenia zjawiska samoleczenia często prowadzonego w sposób bezrefleksyjny i chaotyczny, bez konsultacji z lekarzem, czy nawet bez zapoznania się z treścią ulotki informacyjnej" ${ }^{40}$. Omawiany zakaz ma zmniejszyć nadużywanie leków, skalę uzależnień i zatruć polekowych oraz wynikających z nich kosztów hospitalizacji ${ }^{41}$. W tych samych odpowiedziach Podsekretarz stanu przywołuje liczby dotyczące np. skali zatruć paracetamolem. Nie tłumaczy jednak, dlaczego to zakaz reklamy aptek, a nie samych leków, ma służyć zmniejszeniu tego - skądinąd istotnie negatywnego - zjawiska.

Wydaje się zatem, iż Ministerstwo Zdrowia bezkrytycznie przejęło argumentację prezentowaną przez Naczelną Izbę Aptekarską.

\section{Ocena merytoryczna zakazu}

Całkowity zakaz reklamy aptek od chwili wejścia w życie wywołuje wiele kontrowersji i sprzecznych interpretacji. Podkreślano jego wyjątkową restrykcyjność, jednak początkowo część komentatorów - w opinii Autorki trafnie - wskazywało, iż zakaz reklamy nie powinien być interpretowany jako zakaz wszystkich działań marketingowych, takich jak promocje cenowe czy programy lojalnościowe (Zob. Świerczyński, 2012).

Zdaniem Autorki, obowiązującą obecnie regulację trzeba ocenić jednoznacznie negatywnie (por. np. Koremba, 2009, pkt 94a.4). Mimo iż na gruncie art. 94a prawa farmaceutycznego w brzmieniu obowiązującym przed 1 stycznia 2012 r. powstał szereg spraw, tak na poziomie administracyjnym, jak i sądowo administracyjnym, dotyczących samego pojęcia reklamy, ustawodawca nie pokusił się o wskazanie jej definicji. Wprowadzono natomiast zakaz, który nie dość, że jest nieprecyzyjny, to nie spełnia także funkcji ochrony zdrowia, co miało być intencją ustawodawcy. Jak już wspomniano, jeśli ustawodawca chciał rzeczywiście ograniczyć nadmierną konsumpcję produktów leczniczych, to należało się raczej skupić na bardziej restrykcyjnych przepisach dotyczących reklamy leków, a nie miejsc, w których są one sprzedawane. Stąd, jeśli już, to właściwsze

\footnotetext{
37 Zob. np. pismo Podsekretarza Stanu w Ministerstwie Zdrowia z 24.05.2016 r., PLO.461.273.2016.BRB.

38 Zob. odpowiedź z 31.10.2013 r. na Interpelację nr 21536 i identycznie odpowiedź z 12.12.2013 r. na Interpelację nr 22456 oraz pismo Ministra Zdrowia z 27.05.2013 r. do Marszałka Senatu, MZ-PLO-079-16391-104/PR/13.

39 Zob. odpowiedź z 15.05.2014 r. na interpelację nr 25899 z 7.04.2014 r. w sprawie interpretacji art. 94a ustawy Prawo farmaceutyczne dotyczącego zakazu reklamy aptek i punktów aptecznych

40 Zob. odpowiedź z 31.10.2013 r. na interpelację nr 21536 i identycznie odpowiedź z 12.12.2013 r. na Interpelację nr 22456.

41 Zob. ibidem.
} 
byłoby zakazanie (i jednoznaczne wyartykułowanie tego w treści przepisu) promocji cenowych oraz programów lojalnościowych ${ }^{42}$.

Z jednej strony, ze względu na wyższe dobro, jakim jest ochrona zdrowia i życia człowieka, zrozumiała jest chęć ograniczania spożycia produktów leczniczych do sytuacji, w których jest to niezbędne. $Z$ drugiej zaś - może to powodować konflikt pomiędzy zasadniczym celem prowadzenia apteki, którym, jak w każdej działalności gospodarczej, jest osiągnięcie zysku a zasadami racjonalnego przyjmowania leków. Trzeba jednak pamiętać, iż uprawnionymi do wydawania leków w aptece są magistrowie farmacji oraz technicy farmaceutyczni, a więc osoby z odpowiednim wykształceniem kierunkowym i to oni bezpośrednio decydują o sprzedaży. Oczywiste jest, iż właściciel apteki, jako podmiot bezpośrednio zainteresowany osiągnięciem jak najwyższego zysku, może próbować wywierać presję na personel fachowy, aby osiągnąć wzrost sprzedaży ${ }^{43}$. Wzrost ten może być jednak wygenerowany jedynie w zakresie obrotu lekami OTC oraz innym niż leki i wyroby medyczne asortymentem dostępnym w aptece. Farmaceuta bowiem, nie ma realnego wpływu na ilość i rodzaj leków dostępnych na receptę ordynowanych przez lekarzy.

Należy też pamiętać, iż w wykonywaniu zawodu farmaceuci związani są regułami deontologicznymi zebranymi w Kodeksie Etyki4 ${ }^{44}$, z którymi sprzeczne jest sprzedawanie pacjentom produktów leczniczych, które nie są im potrzebne ze względu na stan zdrowia czy wręcz nakłanianie pacjentów np. do kupowania leków na zapas. Takie przypadki naturalnie zdarzają się, są jednak wyjątkami od reguły, a nie zasadą i ewentualna reklama apteki nie ma na to wpływu.

Obecny zakaz reklamy aptek w żaden sposób nie może wpływać na finanse publiczne, związane z produktami leczniczymi i wyrobami medycznymi objętymi refundacją, ponieważ już w regulacji art. 94a prawa farmaceutycznego w brzmieniu obowiązującym od 1 maja 2007 r. zakazano takiej reklamy. Reklamowanie innej działalności prowadzonej w aptekach pozostaje bez wpływu na finanse publiczne. Co więcej, podstawowa działalność apteki jest wprawdzie regulowana ustawowo, jednak wyliczenie zawarte w art. 86 ust. 1 prawa farmaceutycznego nie ma charakteru katalogu zamkniętego. Świadczy o tym np. dopuszczenie - choć dopiero po wyroku Naczelnego Sądu Administracyjnego ${ }^{45}$ - możliwości umieszczania w aptekach ciśnieniomierzy, służących do samodzielnego pomiaru ciśnienia przez pacjentów. Natomiast co do ograniczenia możliwości reklamowania swoich usług przez przedstawicieli innych wolnych zawodów, należy przyznać, iż rzeczywiście takie obostrzenia istnieją, niemniej w żadnym przypadku nie przybierają aż tak daleko idącej formy.

Po trzecie, wobec ilości produktów leczniczych dopuszczonych obecnie do obrotu na terytorium Polski nie jest możliwe stałe posiadanie pełnego ich asortymentu w magazynie apteki. Wydaje się, iż ustawodawca zdaje sobie z tego sprawę skoro w art. 95 ust. 3 prawa farmaceutycznego przewiduje możliwość zapewnienia leku w uzgodnionym z pacjentem terminie. W praktyce często zdarza się, iż apteki położone blisko określonych przychodni specjalistycznych posiadają w stałej ofercie większe ilości np. produktów leczniczych stosowanych w leczeniu cukrzycy, chorób neu-

\footnotetext{
W kwestii nieadekwatności zakazu reklamy aptek w imię zmniejszenia spożycia produktów leczniczych zob. Koremba (2009) oraz Radowicki Stankiewicz (2011).

43 Wbrew twierdzeniom przedstawicieli samorządu aptekarskiego takie sytuacje zdarzają się zarówno w aptekach należących do farmaceutów, jak i w placówkach sieciowych.

44 Uchwała Nr VI/25/2012 VI Krajowego Zjazdu Aptekarzy z 22.01.2012 r. w sprawie przyjęcia Kodeksu Etyki Aptekarza Rzeczypospolitej Polskiej.

45 Zob. wyr. NSA w Warszawie z 11.01.2012 r.,. II GSK 1365/10.
}

internetowy Kwartalnik Antymonopolowy i Regulacyjny 2016, nr 8(5) • www.ikar.wz.uw.edu.pl • DOI: 10.7172/2299-5749.IKAR.8.5.2 
rologicznych czy onkologicznych. Informowanie o takiej specjalizacji apteki mogłoby przynieść pacjentowi jedynie korzyść. Jest jednak zabronione.

Lobbujące za całkowitym zakazem reklamy środowiska farmaceutyczne opierały swój postulat w dużej mierze na niemożności zapewnienia przez mniejsze apteki cen na poziomie ustalanym przez apteki sieciowe. Dlatego też w zakazie reklamy - w tym informowania pacjentów o cenach - upatrywano możliwości „wyrównania szans”. Tymczasem wprowadzenie zakazu reklamy spowodowało jedynie tyle, że pacjenci muszą osobiście udać się do apteki, aby dowiedzieć się w jakiej cenie jest konkretny preparat. Ponieważ to cena, a nie np. położenie apteki jest bardzo silnym czynnikiem wpływającym na decyzję o miejscu zakupu określonego preparatu, pacjenci często odwiedzają kilka bądź nawet kilkanaście aptek zanim wybiorą najtańszą. Tym samym zakaz reklamy - na co wskazywała Prezes UOKiK - istotnie utrudnił konsumentowi wybranie apteki, która optymalnie odpowiada jego potrzebom ${ }^{46}$. Liczne wystąpienia Prezesa NIA dobitnie wskazują, iż pod pozorem zwalczania reklamy rozumianej jako „wszystko”, co może odróżniać aptekę od innych samorząd stara się zwalczyć również stosowanie obniżek cen przez apteki ${ }^{47}$.

Stanowisko samorządu aptekarskiego i intensywne lobbowanie za zakazem jest tym bardziej kontrowersyjne, że wypowiada się on w imieniu wszystkich farmaceutów. Ponieważ zaś przynależność do właściwej miejscowo okręgowej izby aptekarskiej jest obligatoryjna dla każdego farmaceuty, który chce wykonywać zawód, samorząd wykorzystuje swoją dominującą pozycję, ponieważ obowiązuje w nim jedno „właściwe” stanowisko w zakresie reklamy aptek. Nie zdecydowano się na otwartą debatę, z góry narzucając wszystkim farmaceutom, co jest dla nich dobre ${ }^{48}$. Na wszelki wypadek, by wyeliminować ewentualne głosy sprzeciwu, samorząd zdecydował się nawet na wydanie niezwykle stanowczych w wymowie dokumentów, w których można znaleźć informację, iż samorząd „podejmie wszelkie, prawem przewidziane działania, w celu skutecznego egzekwowania ustanowionego zakazu", a osoba, która narusza nakaz zachowania godności i niezależności zawodu farmaceuty ${ }^{49}$ nie może uzyskać rękojmi należytego prowadzenia apteki, a w konsekwencji nie może pełnić funkcji jej kierownika ${ }^{50}$. W praktyce, zamyka to farmaceucie jedyną dostępną drogę awansu zawodowego.

\section{Perspektywy nowelizacji zakazu reklamy aptek}

Zakaz reklamy aptek w brzmieniu obowiązującym po 1 stycznia 2012 r. powracał kilkukrotnie w interpelacjach poselskich ${ }^{51}$ w Sejmie VII i VIII kadencji. Posłowie zwracali się do Ministra Zdrowia m.in. z pytaniami o przesłanki wprowadzenia zakazu reklamy ${ }^{52}$ oraz plany Ministerstwa w zakresie wyeliminowania dostrzeżonych przez posła niezgodności z prawem ${ }^{53}$. Z przykrością

\footnotetext{
46 Pismo Prezesa UOKiK z 3.12.2008 r., DPR-0799-2(14)/08EU.

47 Zob. pismo z 9.02.2012 r. prezesa Naczelnej Izby Aptekarskiej do Ministra Zdrowia, P-26/2012.

48 Zob. np. Komunikat Prezesa Naczelnej Rady Aptekarskiej z 7.11.2013 r., P-381/2013 w sprawie niepodpisywania przez farmaceutów apelu o zmianę przepisów dot. reklamy aptek sygnowanego przez Związek Pracodawców Aptecznych PharmaNET.

49 W tym wprowadzony do Kodeksu Etyki Zawodowej zakaz reklamy.

50 Zob. Stanowisko Nr VI/1/2012 z 11.04.2012 r. Naczelnej Rady Aptekarskiej w sprawie zakazu reklamy aptek i punktów aptecznych oraz ich działalności.

51 Zob. np. Interpelacja nr 7529 z 25.07.2012 r. w sprawie całkowitego zakazu reklamy aptek i ich działalności, interpelacja nr 22456 z 8.11 .2013 r. do ministra zdrowia w sprawie reklamowania się aptek, interpelacja nr 21536 z 9.10.2013 r. do ministra zdrowia w sprawie wpływu aptecznego zakazu reklam na rozwój krajowej opieki farmaceutycznej i funkcjonowanie aptek, interpelacja 25899 z 7.04.2014 r. w sprawie interpretacji art. $94 a$ ustawy Prawo farmaceutyczne dotyczącego zakazu reklamy aptek i punktów aptecznych.

52 Zob. Interpelacja nr 21536 z 9.10.2013 r. do ministra zdrowia w sprawie wpływu aptecznego zakazu reklam na rozwój krajowej opieki farmaceutycznej i funkcjonowanie aptek.

53 Zob. Interpelacja nr 22456 z 8.11.2013 r. do ministra zdrowia w sprawie reklamowania się aptek.
} 
należy zauważyć, iż odpowiedzi przedstawiane z upoważnienia Ministra Zdrowia na ww. interpelacje są niezwykle schematyczne i nadzwyczaj do siebie podobne, mimo iż pytania zadawane przez posłów wcale nie były identyczne.

Próba doprecyzowania pojęcia „reklamy” poprzez określenie co nią nie jest pojawiła się w 2013 r. ${ }^{54}$. Spotkała się ona z uznaniem środowisk wskazujących na problemy związane m.in. ze sposobem sformułowania zakazu oraz zdecydowaną krytyką - przede wszystkim ze strony samorządu aptekarskiego ${ }^{55}$. Ministerstwo Zdrowia szybko się z tej propozycji wycofało i w kolejnej wersji projektu, który przedstawiono do konsultacji społecznych w dniu 19 września 2013 r. kwestia ta nie została w ogóle poruszona ${ }^{56}$.

\section{Skargi konstytucyjne}

Sprawa całkowitego zakazu reklamy aptek ponownie zainteresowała szersze grono - zarówno posłów, jak i praktyków - w roku 2015, w związku z wniesieniem przez troje przedsiębiorców skarg konstytucyjnych ${ }^{57}$. Argumenty w nich podniesione dotyczą przede wszystkim wspomnianego już wyżej naruszenia reguł dobrej legislacji oraz nieproporcjonalności ograniczenia swobody prowadzenia działalności gospodarczej. Stanowisko zaprezentowane w skardze SK 23/15 spotkało się z kompleksową i przychylną opinią Prokuratora Generalnego ${ }^{58}$, który zauważył m.in., iż:

wprowadzając zakaz reklamy aptek i ich działalności, ustawodawca w niedostatecznym stopniu rozważył możliwość zastosowania środków alternatywnych i określenia ich skuteczności. Możliwe było przecież wprowadzenie zakazu prowadzenia przez apteki określonych form działalności marketingowej czy też używania danego rodzaju środków przekazu, ograniczeń kwoty środków finansowych przeznaczanych na działania marketingowe itp. ${ }^{59}$.

Dwie z wyżej wymienionych skarg ${ }^{60}$ były również przedmiotem dyskusji na posiedzeniu Komisji Ustawodawczej Sejmu61. Uczestniczący w posiedzeniu posłowie, zgodnie z sugestią eksperta z Biura Analiz Sejmowych, zdecydowaną większością wyrazili negatywną opinię o zgodności art. 94a ust. 1 ustawy z dnia 6 września 2001 r. - Prawo farmaceutyczne z art. 20 oraz art. 22 w związku z art. 31 ust. 3, art. 49 i art. 54 ust. 1 Konstytucji oraz wnieśli o umorzenie postępowania przed Trybunałem Konstytucyjnym ${ }^{62}$.

Zarówno stanowisko przedstawione przez Prokuratora Generalnego, jak i opinie Komisji Ustawodawczej spotkały się z ogromną krytyką ze strony części środowiska farmaceutów63.

\footnotetext{
54 Zob. Projekt założeń do projektu ustawy o zmianie ustawy o refundacji leków, środków spożywczych specjalnego przeznaczenia żywieniowego oraz wyrobów medycznych i niektórych innych ustaw z 19.04.2013 r., Wykaz Prac Legislacyjnych Rady Ministrów, numer ZD68; punkt 3.18.1.2.

55 Zob. np. pismo Naczelnej Izby Aptekarskiej z 16.05.2013 r., P-199/2013 i zawarta tam teza, iż problemem nie jest sam zakaz, a jedynie niedostatecznie zdecydowane jego egzekwowanie przez odpowiednie organy nadzoru farmaceutycznego.

56 Projekt założeń do projektu ustawy o zmianie ustawy o refundacji leków, środków spożywczych specjalnego przeznaczenia żywieniowego oraz wyrobów medycznych i niektórych innych ustaw z 18.09.2013 r., Wykaz Prac Legislacyjnych Rady Ministrów, numer UD130. Uwagę na pominięcie w tym projekcie zagadnień związanych z zakazem reklamy aptek podniesiono np. w uwagach zgłoszonych do tej wersji projektu przez Związek Pracodawców Aptecznych PharmaNET. Pozyskano z: https://legislacja.rcl.gov.pl/projekt/178080/katalog/178084\#178084

57 Zob. skarga konstytucyjna z 16.03.2015 r., SK 23/15, skarga konstytucyjna z 3.06.2015 r., SK 32/15 oraz skarga konstytucyjna z 15.01.2016 r., SK 11/16.

58 Zob. Stanowisko Prokuratora Generalnego z 26.01.2016 r., znak: PG VIII TK 69/15.

59 Ibidem, s. 36

60 Skargi SK 23/15 oraz SK 32/15.

61 Zob. pełny zapis przebiegu posiedzenia Komisji Ustawodawczej nr 12 z 30.03.2016 r., s. 5-9.

62 Zob. Opinia nr 35 Komisji Ustawodawczej uchwalona w dniu 30 marca 2016 r. dla Marszałka Sejmu w sprawie skargi konstytucyjnej sygn. akt SK $23 / 15$ oraz Opinia nr 36 Komisji Ustawodawczej uchwalona w dniu 30 marca 2016 r. dla Marszałka Sejmu w sprawie skargi konstytucyjnej sygn. akt SK $32 / 15$. 63 Zob. np. Stanowisko Naczelnej Izby Aptekarskiej z 18.02.2016 r. w sprawie opinii Prokuratora Generalnego na temat zakazu reklamy aptek, pismo Okręgowej Izby Aptekarskiej w Białymstoku z 31.03.2016 r. do Ministra Sprawiedliwości i Prokuratora Generalnego, L.dz. 46/2016, Rezolucja nr RA/2/VII/16 z 16.06.2016 r. Okręgowej Rady Aptekarskiej Dolnośląskiej Izby Aptekarskiej we Wrocławiu w sprawie działań podejmowanych przez
} 
W dniu 6 września 2016 r. Prokurator Generalny przedstawił stanowisko dodatkowe, modyfikujące wystąpienie z dnia 23 listopada 2015 r. $^{64}$. Nowy Prokurator Generalny stoi na stanowisku, iż art. 94a ust. I prawa farmaceutycznego jest zgodny z art. 20 i art. 22 w związku z art. 31 ust. 3 Konstytucji Rzeczypospolitej Polskiej, z art. 54 ust. I w związku z art. 31 ust. 3 Konstytucji RP, z art. 49 w związku z art. 31 ust. 3 Konstytucji RP oraz z zasadą określoności prawa, wywiedzioną $z$ art. 2 Konstytucji RP65.

Ubolewać należy, iż krytyka wyrażana przez samorząd aptekarski nie jest równie umotywowana, jak nasilona. Wzorzec sumiennego (niereklamującego swoich usług) farmaceuty z apteki rodzinnej przeciwstawiany jest nastawionym wyłącznie na zysk sieciom aptecznym, które dysponując ogólnie większym kapitałem, mogą potencjalnie przeznaczyć większe sumy na działania reklamowe. Jakkolwiek niektórzy z autorów posuwają się do bardzo kategorycznych stwierdzeń66 nie przedstawiają na nie żadnych dowodów. Nie wiadomo bowiem czemu farmaceuta pracujący w aptece, o której działalności można informować (nie mówiąc już nawet o reklamie), miałby wykonywać swoje obowiązki zawodowe gorzej niż obecnie.

Z kolei w stanowisku Naczelnej Izby Aptekarskiej, jako uzasadnienie podtrzymania całkowitego zakazu reklamy, wskazano, że do tej regulacji dochodzono stopniowo, z uwagi na fakt, że zakaz w brzmieniu wprowadzonym w 2007 r. nie odniósł zamierzonego skutku. Ma to zatem dowodzić, iż ustawodawca przed wprowadzeniem zakazu rozważył dostatecznie możliwość zastosowania środków alternatywnych ${ }^{67}$. Niestety także w tym przypadku przedstawiciele samorządu aptekarskiego ograniczyli się do krytyki, nie podając choćby jednego przykładu na brak osiągnięcia skutku przez zakaz z 2007 r.

\section{Podsumowanie}

W opinii Autorki, istotnie nie należy zapominać o fakcie, iż pacjent jest specyficznym klientem, który - w zaufaniu do kompetencji farmaceutów - zwraca się do personelu fachowego apteki po poradę i najczęściej istotnie nabywa polecony przez nich produkt. Niestety, przedstawiciele samorządu zawodowego, walcząc bardziej o ujednolicenie sytuacji aptek niż o interes pacjenta, wydają się mylić przyczyny i skutki działań tak przedsiębiorców, jak i pacjentów. Spożycie produktów leczniczych i suplementów diety jest w Polsce rzeczywiście zastraszająco wysokie. Po pierwsze jednak, jak słusznie zauważono w przywołanym powyżej stanowisku Prokuratora Generalnego, zwiększenie spożycia produktów leczniczych jest przede wszystkim wywoływane ich wszechobecną, choć zgodną z prawem reklamą, a nie promowaniem aptek. Po drugie, nie wykazano, żeby obowiązujący już ponad 4 lata zakaz reklamy aptek był skuteczny, skoro nadal obserwować można wzrost konsumpcji leków68.

\footnotetext{
Naczelną Izbę Aptekarską w związku z opinią Prokuratora Generalnego w przedmiocie niekonstytucyjności zakazu reklamy aptek, stanowiskiem Komisji Ustawodawczej Sejmu RP dot. niekonstytucyjności zakazu reklamy aptek oraz nasilającego się zjawiska łamania zakazu aptek, Jędrzejczak (2016).

64 Należy podkreślić, iż z dniem 4 marca 2016 r., wyniku połączenia urzędów, nastąpiła zmiana na stanowisku Prokuratora Generalnego - objął je Minister Sprawiedliwości.

65 Zob. http://ipo.trybunal.gov.pl/ipo/dok?dok=F52344424\%2FSK_23_15_pg_2016_09_06_ADO.pdf (22.11.2016 r.).

66 Zob. „(...) przytaczane przez przeciwników zakazu reklamy aptek argumenty, wśród których pojawiają się treści kłamliwe i zmanipulowane, mające ośmieszyć obowiązujące prawo, znalazły się w wypowiedzi eksperta z Biura Analiz Sejmowych na posiedzeniu sejmowej Komisji Ustawodawczej” (Jędrzejczak, 2016, s. 2).

67 Zob. Stanowisko Naczelnej Izby Aptekarskiej z 18.02.2016 r. w sprawie opinii Prokuratora Generalnego na temat zakazu reklamy aptek, s. 2.

68 Zob. Stanowisko Prokuratora Generalnego z 26.01.2016 r., PG VIII TK 69/15, s. 35.
} 
Wniesione przez przedsiębiorców skargi konstytucyjne pozwalają żywić nadzieję, że orzeczenia Trybunału Konstytucyjnego będą stanowić dla ustawodawcy impuls do ponownego przeanalizowania regulacji dotyczącej zakazu reklamy aptek i jej harmonizacji z relewantnymi przepisami określającymi reklamę produktów leczniczych, wyrobów medycznych i suplementów diety, tak by praktycznie, a nie jedynie iluzorycznie chronić zdrowie pacjentów.

\section{Bibliografia}

Bańka, M. (2003). Wielki Słownik Wyrazów Obcych. Warszawa: PWN.

Harasymiuk, D. (2011). Zakazy reklamy towarów w prawie polskim i europejskim. Oficyna Wolters Kluwer. Pozyskano z: system Lex Omega (12.07.2016 r.).

Jędrzejczak, M. (2016). Argumenty za zniesieniem zakazu reklamy aptek są kłamliwe i zmanipulowane. Pozyskano z: http://www.rynekaptek.pl/wywiad/argumenty-za-zniesieniem-zakazu-reklamy-aptek-sa -klamliwe-i-zmanipulowane,13852_3.html (12.07.2016 r.).

Koremba, M. (2009). Komentarz do art. 94 a ustawy - Prawo farmaceutyczne. W: M. Kondrat (red.), Prawo farmaceutyczne. Komentarz. Wolters Kluwer. Pozyskano z: system Lex Omega (12.07.2016 r.).

Kwarciak, B. (1999). Co trzeba wiedzieć o reklamie. Kraków: Wydawnictwo Profesjonalnej Szkoły Biznesu. Ogiegło, L. (2015). Prawo farmaceutyczne. Komentarz. Warszawa: Wydawnictwo C.H. Beck.

Radowicki, S., Stankiewicz, R. (2011). Zakaz reklamy aptek i punktów aptecznych. Manager Apteki, 9. Świerczyński, M. (2012). Zmiany dotyczące reklamy wynikające z innych ustaw pakietu zdrowotnego. W: M. Namysłowska. Reklama. Aspekty prawne. Pozyskano z: system Lex Omega (12.07.2016 r.). 